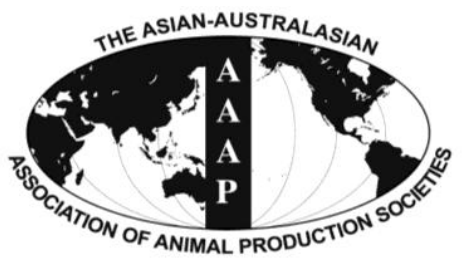

Asian-Aust. J. Anim. Sci.

Vol. 25, No. 12 : 1759-1767 December 2012

http://dx.doi.org/10.5713/ajas.2012.12416

www.ajas.info

pISSN 1011-2367 elSSN 1976-5517

\title{
Effects of Dietary Fat Types on Growth Performance, Pork Quality, and Gene Expression in Growing-finishing Pigs
}

\author{
J. C. Park ${ }^{\mathrm{a}}$, S. C. Kim ${ }^{1, a}$, S. D. Lee, H. C. Jang ${ }^{1}$, N. K. Kim ${ }^{1}$, S. H. Lee ${ }^{1}$, H. J. Jung, \\ I. C. Kim, H. H. Seong ${ }^{1}$ and B. H. Choi ${ }^{1}{ }^{*}$ \\ Swine Science Division, National Institute of Animal Science, Rural Development Administration, \\ Cheon-an, Chungnam 330-801, Korea
}

\begin{abstract}
This study was performed to determine the effects of dietary fat sources, i.e., beef tallow, soybean oil, olive oil and coconut oil (each $3 \%$ in feed), on the growth performance, meat quality and gene expression in growing-finishing pigs. A total of 72 crossbred pigs (Landrace $\times$ Large White $\times$ Duroc) were used at $71 \pm 1 \mathrm{~kg}$ body weight (about $130 \mathrm{~d}$ of age) in 24 pens $(320 \times 150 \mathrm{~cm})$ in a confined pig house (three pigs per pen) with six replicate pens per treatment. The growing diet was given for periods of $14 \pm 3 \mathrm{~d}$ and the finishing diet was given for periods of $28 \pm 3 \mathrm{~d}$. The fat type had no significant effect either on growth performance or on chemical composition or on meat quality in growing-finishing pigs. Dietary fat type affected fatty acid composition, with higher levels of unsaturated fatty acids (UFAs) and monounsaturated fatty acids (MUFAs) in the olive oil group. Microarray analysis in the Longissimus dorsi identified 6 genes, related to insulin signaling pathway, that were differentially expressed among the different feed groups. Real time-PCR was conducted on the six genes in the longissimus dorsi muscle (LM). In particular, the genes encoding the protein kinase, cAMP-dependent, regulatory, type II, alpha (PRKAR2A) and the catalytic subunit of protein phosphatase 1, beta isoform (PPP1CB) showed the highest expression level in the olive oil group (respectively, $\mathrm{p}<0.05, \mathrm{p}<0.001$ ). The results of this study indicate that the type of dietary fat affects fatty acid composition and insulin signaling-related gene expression in the LM of pigs. (Key Words: Dietary Fat, Fatty Acid, Gene Expression, Growing-finishing Pig, Insulin Signaling Pathway)
\end{abstract}

\section{INTRODUCTION}

Feeding strategy is the most commonly used management factor for quality control in the production of meat and for improvement or control of performance, animal welfare, safety, nutritional value, and eating and technological quality (Andersen et al., 2005). Fat supplementation is important for growing-finishing pigs because of the high energy value of the diet. Fats are characterized by low heat production (Noblet et al., 1994) and have the advantage of lowering the dietary heat increment of growing-finishing pigs during periods of environmental heat stress (Spencer et al., 2005).

There has been a recent increase in consumer preference

\footnotetext{
* Corresponding Author: Bong-Hwan Choi. Tel: +82-31-2901592, Fax: +82-31-290-1792, E-mail: bhchoi@ korea.kr

${ }^{1}$ Division of Animal Genomics \& Bioinformatics, National Institute of Animal Science, Rural Development Administration, Chuksan gil 77, Kwonsun-gu, Suwon, Korea.

${ }^{a}$ These authors contributed equally to this work.

Submitted Aug. 3, 2012; Accepted Sept. 4, 2012; Revised Sept. 16, 2012
}

for products with higher levels of unsaturated fatty acids (UFAs) because of their beneficial effects in the diet, such as prevention of cardiovascular disease (Van Deckel et al., 1996). Increased intake of polyunsaturated fatty acids (PUFAs) lowers the risk for cardiovascular disease, and there is therefore a great deal of consumer interest in these compounds (Corino et al., 2002). Pig diets supplemented with vegetable oils such as soybean, sunflower and rapeseed oils contain high levels of UFAs and may lead to healthier products for consumers. For example, soybean oil has been used as a fat source with a relatively high concentration of PUFAs (Eder et al., 2005). Although UFAs from vegetable oil affect pork quality, the effects have yet to be characterized in detail.

Meat quality of pigs is affected by breed, nutritional status, and the feeding system used in fattening. Intramuscular fat (IMF) deposition and back fat thickness (BF) are important factors in meat quality and are among the most important candidate traits for understanding the interactions between nutrition and gene expression during meat quality formation in pigs (Yin and Li, 2009). Collected 
data also indicate that nutritional factors can interact with other regulatory networks such as tissue-specific, developmental, and hormonal factors, as well as dietary fat or carbohydrate to regulate gene expression.

This study was performed to evaluate the impacts of dietary fat type on the growth performance, meat quality, and differential gene expression in growing-finishing pigs.

\section{MATERIAL AND METHODS}

\section{Animals and diets}

Seventy-two crossbred pigs (Landrace $\times$ Large White $\times$ Duroc) were used. The animals, at $71 \pm 1 \mathrm{~kg}$ body weight (about $130 \mathrm{~d}$ of age), were randomly allocated into 24 pens $(320 \times 150 \mathrm{~cm}$ with solid concrete flooring) in a confined pig house, with three pigs per pen and six replicate pens per treatment. Treatment groups consisted of the same numbers of gilts and barrows. Each pen was equipped with a nipple waterer and a stainless steel feeder, and the pigs were given free access to feed and water throughout. Animals received care in accordance with the Guide for the Care and Use of Laboratory Animals (National Institute of Animal Science Animal Care Committee).

The ingredients and chemical compositions of the growing and finishing diets used in this experiment are shown in Table 1. All other nutrient requirements met or exceeded the NRC recommendations for growing and finishing pigs (NRC, 1998). Fat sources used in the present study were beef tallow, coconut oil, olive oil, and soybean oil, which were added to a concentration of $3.0 \%$ in feed. The fat sources were melted at approximately $50{ }^{\circ} \mathrm{C}$, and the melted fats were diluted approximately $10 \%$ in the diets. The $10 \%$ fat diets were then formulated to $3.0 \%$ fats supplied to each diet. The growing diet was given to crossbred pigs for experimental periods of $14 \pm 3 \mathrm{~d}$. The finishing diet was given to crossbred pigs for experimental periods of $28 \pm 3 \mathrm{~d}$. Pig weights and feed intakes were determined weekly to calculate the average daily gain (ADG, $\mathrm{kg} / \mathrm{d}$ ) and average daily feed intake (ADFI, $\mathrm{kg} / \mathrm{d}$ ). The ratio of gain to feed was calculated from ADG and ADFI.

\section{Slaughtering and sampling}

Pigs of $102 \pm 3 \mathrm{~kg}$ live weight were transported to a standard abattoir near the experimental station. The pigs were slaughtered $12 \mathrm{~h}$ after feed restriction. They were stunned electrically ( $300 \mathrm{~V}$ for $3 \mathrm{~s}$ ) with a pair of stunning tongs, shackled by the right leg, and exsanguinated while hanging. The carcasses were placed in a dehairer at $62^{\circ} \mathrm{C}$ for $5 \mathrm{~min}$, and the remaining hair was removed using a knife and flame after exit from the dehairer. The carcasses were eviscerated and split before being placed in a chiller set at $4^{\circ} \mathrm{C}$ for $12 \mathrm{~h}$. For determination of chemical compositions and meat quality parameters, the longissimus
Table 1. Composition of experiment diets, as-fed basis

\begin{tabular}{|c|c|c|}
\hline Items & Growing & Finishing \\
\hline \multicolumn{3}{|l|}{ Ingredients (\%) } \\
\hline Corn grain & 62.38 & 57.64 \\
\hline Soybean meal & 22.00 & 14.00 \\
\hline Wheat & 10.00 & 11.00 \\
\hline Wheat bran & 0.00 & 12.00 \\
\hline Fat source $^{1}$ & 3.00 & 3.00 \\
\hline L-lysine & 0.06 & 0.06 \\
\hline Limestone & 0.65 & 1.10 \\
\hline Tricalcium phosphate & 1.11 & 0.30 \\
\hline Sodium chloride & 0.30 & 0.30 \\
\hline Vitamin+mineral premix ${ }^{2}$ & 0.40 & 0.40 \\
\hline Antibiotics & 0.10 & 0.00 \\
\hline \multicolumn{3}{|l|}{ Chemical composition $^{3}$} \\
\hline $\mathrm{DE}(\mathrm{kcal} / \mathrm{kg})$ & 3,500 & 3,400 \\
\hline Crude protein $(\%)$ & 15.44 & 13.42 \\
\hline Crude fat $(\%)$ & 5.50 & 5.67 \\
\hline Crude fiber $(\%)$ & 3.45 & 3.94 \\
\hline Lysine (\%) & 0.82 & 0.66 \\
\hline Methionine+cystine (\%) & 0.52 & 0.47 \\
\hline Calcium (\%) & 0.69 & 0.60 \\
\hline Phosphorus (\%) & 0.54 & 0.47 \\
\hline
\end{tabular}

${ }^{1}$ Fat source: Beef tallow, soybean oil, olive oil, coconut oil.

${ }^{2}$ The vitamin and mineral per kilogram of the diet provided by premix: Vitamin A, 2,000,000 IU; Vitamin $\mathrm{D}_{3}$, 400,000 IU; Vitamin E, 2,500 IU; Vitamin $\mathrm{K}_{3}, 100 \mathrm{mg}$; Vitamin $\mathrm{B}_{1}, 100 \mathrm{mg}$; Vitamin $\mathrm{B}_{2}, 300 \mathrm{mg}$; Vitamin $\mathrm{B}_{12}$, 1,200 mcg; Niacin, 2,000 mg; d-Pantothenicalcium, 1,000 mg; Folic acid, $200 \mathrm{mg}$; Biotin, $20 \mathrm{mg}$; Choline chloride, 25,000 mg; Mn, 12,000 mg; Zn, 15,000 mg; Fe, 4,000 mg; Cu, 500 mg; I, 250 mg; Co, 100 mg; $\mathrm{Mg}, 2,000 \mathrm{mg}$; B.H.T., 5,00 mg.

${ }^{3}$ Chemical composition was calculated from ingredient proportion.

dorsi muscle (LM, 6th to 13th rib) was removed and kept at $4^{\circ} \mathrm{C}$ for transport to the laboratory.

\section{Chemical compositions and meat quality parameters}

About $24 \mathrm{~h}$ after slaughter, the contents of moisture, crude protein, crude fat, and crude ash in samples of LM were determined according to AOAC method (AOAC, 1990). For the determination of shear force, samples were cooked individually in plastic bags immersed in a water bath at $75^{\circ} \mathrm{C}$ for $30 \mathrm{~min}$. The cooked meat was cooled and sampled at room temperature using a $12.7-\mathrm{mm}$ circular core to determine shear force. Four sample cores from each sample were sheared across the length of the core with a Warner-Bratzler shear attachment (V-type blade set) on a texture analyzer (TA-XT2i; Stable Micro Systems, Godalming, Surrey, UK), at a cross-head speed of $2 \mathrm{~mm} / \mathrm{s}$. Texture Expert for Windows ${ }^{\mathrm{TM}}$ was used to analyze the data. The shear force value, measured in units of $\mathrm{kg}$, was the mean of the maximum forces required to shear each set of core samples. Cooking losses were determined as described by (Honikel, 1998). For measurement of $\mathrm{pH}_{24}, 2$-g samples of LM were homogenized at about $24 \mathrm{~h}$ postmortem in 10 
volumes of distilled water using a Polytron homogenizer (MSE Scientific Instruments, Manor Royal, Crawley, Surrey, UK). The pH was measured using a Hanna HI 9025 pH meter (Hanna Instruments, Woonsocket, RI, USA) with an Orion 8163 glass electrode (Orion, Beverly, MA, USA). Water holding capacity (WHC) was determined by a centrifugal method as described by (Jauregui et al., 1981).

For determination of fatty acids in LM, extracted fat samples were prepared from LM after estimation of meat quality parameters. Meat fat was extracted from the ground muscle using a modification of the Folch wash method (Folch et al., 1957), as described by Ways and Hanahan (1964). Fatty acids were quantified as their fatty acid methyl esters (FAMEs), prepared by acid-catalyzed methanolysis. The FAMEs in the hexane layer were analyzed by chromatography (Agilent-6890+; Agilent Technologies, Santa Clara, CA, USA) with a flame ionization detector and split (50:1) injector. The samples were methylated in duplicate and were injected twice onto a gas-liquid chromatography (GLC) column. FAME separation was performed on an Omegawax 320 capillary GLC column $(30 \mathrm{~m} \times 0.32 \mathrm{~mm}$ i.d, $0.25 \mathrm{~mm}$ film thickness; Supelco, Bellefonte, PA, USA) using $\mathrm{N}$ as the carrier gas. Flame ionization detector and injector temperatures were fixed at $260^{\circ} \mathrm{C}$ and $250^{\circ} \mathrm{C}$, respectively. The oven temperature was set to $200^{\circ} \mathrm{C}$ for $40 \mathrm{~min}$. Data were recorded and analyzed on a ChemStation system (G1701CA Version C.00; Agilent).

\section{Collection of animal tissues and ribonucleic acid} extraction

Immediately after slaughter, 24 LM samples were taken from animals in the four dietary groups, frozen in liquid nitrogen, and stored at $-80^{\circ} \mathrm{C}$ until preparation of total RNA. The muscle was powdered with liquid nitrogen, and total RNA was extracted from $1 \mathrm{mg}$ of muscle tissue using $3 \mathrm{ml}$ of TRIzol ${ }^{\circledR}$ reagent (Invitrogen, Inc., Carlsbad, CA, USA). RNA quality was confirmed by examining the $28 \mathrm{~S}$ and $18 \mathrm{~S}$ rRNA bands on $1.5 \%$ agarose gels stained with ethidium bromide. Total RNA was extracted from all samples using an RNeasy Lipid Tissue Midi Kit (Qiagen, Valencia, CA, USA).

\section{DNA microarray hybridization and microarray scanning and image analysis}

Differentially expressed gene (DEG) analysis using a GeneChip $^{\circledR}$ porcine genome array (Affymetrix Inc., Santa Clara, CA, USA) was performed in LM tissue from 24 pigs fed beef tallow, coconut oil, olive oil, or soybean. Aliquots of $1 \mu \mathrm{g}$ of mRNA were converted into double-stranded cDNA using a GeneChip ${ }^{\circledR}$ Expression 3'-Amplification One Cycle Synthesis kit (Affymetrix Inc.). Hybridization cocktail $(200 \mu \mathrm{l})$ containing $15 \mu \mathrm{g}$ of fragmented cRNA were injected into the porcine genome array chip, and the array was scanned with a GeneChip ${ }^{\circledR}$ Scanner 3000 (Affymetrix Inc.). The fluidic station and scanner were managed by GeneChip ${ }^{\circledR}$ operating software (GCOS 1.3; Affymetrix Inc.).

\section{Data preprocessing, clustering and biological data mining}

The GeneChip ${ }^{\circledR}$ porcine genome array contains 23,937 probe sets to interrogate 23,256 transcripts in pigs, which represents 20,201 genes. Fold change and Welch's $t$-test were applied to select the genes for further analysis. The genes showing 2-fold differential expression were clustered using hierarchical clustering with Pearson's correlation as a similarity measure and complete linkage as a linkage method. GenPlex ${ }^{\mathrm{TM}}$ v2.4 software (Istech Inc., Goyang City, South Korea) was used for cluster analysis. Gene ontology significance analysis was performed to investigate the functional relationships of the 2-fold DEGs, using highthroughput GoMiner. The 2-fold DEGs were mapped to relevant pathways using GenPlex ${ }^{\mathrm{TM}}$ v2.4 software. The pathway resources were taken from the Kyoto Encyclopedia of Genes and Genomes (KEGG) database.

\section{Quantitative real time polymerase chain reaction (RT- PCR) analysis}

To validate the six DEGs related to insulin signaling, based on the KEGG database, in the LM of 3 barrows in each treatment group, we performed quantitative real-time PCR (RT-PCR) with an ABI 7500 Real-Time PCR apparatus (Applied Biosystems, Foster City, CA) in 96-well plates. All primer sets were designed using sequence information from the NetAff ${ }^{\mathrm{TM}}$ Analysis Center (http://www.affymetrix.com/analysis/index.affx) using the Primerquest program (http://www.idtdna.com/Scitools/ Applications/Primerquest/). The $\beta$-actin gene (GenBank Acc. No. AY550069) was used as an internal control. Complementary DNA (cDNA) synthesis was performed by reverse transcription using SuperScript ${ }^{\mathrm{TM}}$ II reverse transcriptase (Invitrogen, Inc., Carlsbad, CA, USA) as follows. Aliquots of $4 \mu \mathrm{l}$ of total RNA were preincubated with $0.5 \mu \mathrm{g}(1 \mu \mathrm{l})$ of random primer mix (Promega Co., Madison, WI, USA) and $2.5 \mathrm{mM}(1 \mu \mathrm{l}) \mathrm{dNTP}$ mix at $65^{\circ} \mathrm{C}$ for $5 \mathrm{~min}$. The tubes were placed on ice, and $4 \mu \mathrm{l}$ of $5 \times$ first-stand buffer (250 mM Tris- $\mathrm{HCl}, \mathrm{pH} 8.3,375 \mathrm{mM} \mathrm{KCl}$, $15 \mathrm{mM} \mathrm{MgCl} 2), 2 \mu \mathrm{l}$ of $0.1 \mathrm{M} \mathrm{DTT}$, and 40 units $(0.5 \mu \mathrm{l})$ of RNase inhibitor (Promega) were added, followed by incubation at $42^{\circ} \mathrm{C}$ for $2 \mathrm{~min}$. Then, 200 units $(1 \mu \mathrm{l})$ of SuperScript $^{\mathrm{TM}}$ II reverse transcriptase (Invitrogen) were added and incubation was continued at $42^{\circ} \mathrm{C}$ for $50 \mathrm{~min}$. Reverse transcriptase activity was terminated by incubation 
at $70^{\circ} \mathrm{C}$ for $15 \mathrm{~min}$ (Table 6). Using this cDNA, RT-PCR was performed in a total volume of $20 \mu \mathrm{l}$ containing $2 \mu \mathrm{l}$ of cDNA $(0.1 \mu \mathrm{g} / \mu \mathrm{l}), 10 \mu \mathrm{l}$ of $2 \times \mathrm{SYBR}^{\circledR}$ Green PCR Master Mix (Applied Biosystems), and $1 \mu \mathrm{l}$ of $10 \mathrm{pM}$ forward and reverse primers. The amplification reaction was started by incubation for $2 \mathrm{~min}$ at $50^{\circ} \mathrm{C}$, followed by 40 cycles of $95^{\circ} \mathrm{C}$ for $10 \mathrm{~min}, 95^{\circ} \mathrm{C}$ for $10 \mathrm{~s}$, and $60^{\circ} \mathrm{C}$ for $1 \mathrm{~min}$. After 36 cycles, a final extension step was performed at $72^{\circ} \mathrm{C}$ for $1 \mathrm{~min}$. RT-PCR for each gene was repeated three times. Following amplification, melting curve analysis was performed to verify the specificity of the reactions. The endpoint used in real-time RT-PCR quantification $(\mathrm{Ct})$ was defined as the PCR threshold cycle number. The $\Delta \mathrm{Ct}$ value was determined by subtracting the $\beta$-actin $\mathrm{Ct}$ value for each sample from the target $\mathrm{Ct}$ value. Finally, we transformed the expression level to the $2^{-\mathrm{ACt}}$ value for further analysis.

\section{Statistical analysis}

Statistical analyses were performed using the general linear model (GLM) procedure with the Statistical Analysis Systems Institute software package (SAS). The data of growth performance and meat quality were subjected to analysis of least square means in a completely randomized design. The model included the effects of fat sources. The results are given as means and pooled standard errors. Differences were considered statistically significant at $\mathrm{p}<0.05$.

To identify DEGs among the different dietary fat groups, statistical analysis was performed by analysis of variance (ANOVA) using the MIXED procedure with the $\mathrm{R}$ statistical package (http://www.R-project.org) for animals nested within age as the random effect. We also examined the least square means (LSM) for testing the significance of differences among the groups, using Duncan's multiple range test. The following statistical model was used to estimate the effects of dietary group on individual gene expression:

$$
Y_{i j}=\mu+F E D_{i}+D A Y_{j}+e_{i j}
$$

Where $Y_{i j}$ is the target gene intensity $\left(2^{-\Delta \mathrm{Ct}}\right), \mu$ is the overall mean, $F E D_{i}$ is the fixed effect of the $i$ th dietary type, and $D A Y_{j}$ is animals nested within age as a random effect.

\section{RESULTS AND DISCUSSION}

The effect of fat source on growth performance was shown in Table 2. Average daily gain (ADG, $\mathrm{kg} / \mathrm{d}$ ) and average daily feed intake (ADFI, $\mathrm{kg} / \mathrm{d}$ ) were significantly higher $(\mathrm{p}<0.05)$ in the beef tallow group than in the coconut oil group. However, ADG and ADFI in the soybean oil and olive oil groups were not significantly different from those in the beef tallow and coconut oil groups. Therefore, feed efficiency was not shown significant difference by type of fat source. These results consist that ADG and feed efficiency was not influenced by difference of fat sources in the pigs (Ewan, 1970; McDonald and Hamilton, 1976; Seerley et al., 1978). Also, Mitchaothai et al. (2007) reported that ADG and ADFI were not significantly different between pigs fed either a beef tallow or sunflower oil diet. When pigs were fed coconut oil in combination with tallow or corn oil, the growth rates were intermediate between those in pigs fed each fat source alone. None of the dietary lipid combinations resulted in a beneficial growth response to supplemental coconut oil, particularly when compared with long chain fatty acid of vegetable and animal lipid sources (Cera et al., 1989).

In many other reports, the addition of fat at the diet was known to improve feed efficiency during the post-weaning period (Cera et al., 1988; 1990; Howard et al., 1990; Li et al., 1990; Overland et al., 1993; Tokach et al., 1995). However, initial stage (from 0 to $14 \mathrm{~d}$ after weaning) was also no difference of feed efficiency. It was only improved post-weaning stage (from 14 to $35 \mathrm{~d}$ after weaning). This result was suggested effects by differences of energy metabolism following a growth phase.

The effects of fat source on the chemical composition of the LM are shown in Table 3. The contents of moisture, crude fat, and crude ash in the LM were similar between all treatment groups. The crude protein level in the LM was significantly higher $(\mathrm{p}<0.05)$ in the beef tallow group than in the soybean oil group. However, the LM crude protein levels in the olive oil and coconut oil groups were not significantly different from those in the beef tallow and soybean oil groups. Also, the values of the meat quality

Table 2. The effect of dietary fat source on growth performance in pigs ${ }^{1}$

\begin{tabular}{lccccc}
\hline Items & Beef tallow & Coconut oil & Olive oil & Soybean oil & SE \\
\hline Initial weight $(\mathrm{kg})$ & 70.06 & 71.27 & 71.07 & 72.02 & 1.762 \\
Final weight $(\mathrm{kg})$ & 104.77 & 100.04 & 101.11 & 103.70 & 2.242 \\
ADG $(\mathrm{kg} / \mathrm{d})$ & $0.91^{\mathrm{a}}$ & $0.77^{\mathrm{b}}$ & $0.81^{\mathrm{ab}}$ & $0.85^{\mathrm{ab}}$ & 0.037 \\
$\mathrm{ADF},(\mathrm{kg} / \mathrm{d})$ & $2.54^{\mathrm{a}}$ & $2.35^{\mathrm{b}}$ & $2.52^{\mathrm{ab}}$ & $2.46^{\mathrm{ab}}$ & 0.053 \\
Feed efficiency & 0.36 & $0.36^{\mathrm{b}}$ & 0.33 & 0.34 & 0.016 \\
\hline
\end{tabular}

\footnotetext{
${ }^{1}$ There were 18 pigs per diet group. The pooled SE from ANOVA is indicated.
}

${ }^{a, b}$ Means with different superscripts in the same row are different at $\mathrm{p}<0.05$. 
Table 3. The effect of dietary fat source on chemical composition and meat quality parameters of LM in pigs ${ }^{1}$

\begin{tabular}{lccccc}
\hline Items & Beef tallow & Coconut oil & Olive oil & Soybean oil & SE \\
\hline Moisture (\%) & 74.08 & 73.30 & 74.01 & 79.87 & 0.411 \\
Crude protein (\%) & $23.33^{\mathrm{a}}$ & $22.84^{\mathrm{ab}}$ & $22.88^{\mathrm{ab}}$ & $22.71^{\mathrm{b}}$ & 0.191 \\
Crude fat (\%) & 1.20 & 2.31 & 1.81 & 1.70 & 0.461 \\
Crude ash (\%) & 1.16 & 1.13 & 1.14 & 1.14 & 0.024 \\
Shear force (kg/0.5 inch) & 3.46 & 3.80 & 3.49 & 3.96 & 0.229 \\
Cooking loss (\%) & $34.56^{\mathrm{ab}}$ & $34.14^{\mathrm{b}}$ & $35.83^{\mathrm{a}}$ & $33.68^{\mathrm{b}}$ & 0.040 \\
$\mathrm{pH}_{24}$ & 5.58 & 5.60 & 5.63 & 5.60 & 0.040 \\
Water holding capacity (\%) & 52.66 & 53.22 & 53.16 & 54.71 & 0.787 \\
\hline
\end{tabular}

${ }^{1}$ There were 18 pigs per diet group. The pooled SE from ANOVA is indicated.

${ }^{a, b}$ Means with different superscripts in the same row are different at $\mathrm{p}<0.05$.

parameters of the LM by type of fat source are presented in Table 3. The shear force of the LM was not significantly different among the treatment groups. Cooking loss was significantly higher in the olive oil group than in the soybean oil and coconut oil groups but the effects of beef tallow on cooking loss from the LM were not significantly different from those of soybean, olive, and coconut oils. The $\mathrm{pH}_{24}$ and water holding capacity in the LM were similar between all treatment groups. It was shown that the fat type had no significant effect on chemical composition and on meat quality in the LM. Teye et al. (2006) evaluated the effects of three dietary oils (palm kernel, palm, and soybean oils) and two protein levels (high and low) on growth performance and meat quality in 60 pigs. The study which did not significantly affect growth or carcass quality by oil type is consistent with our result (Scheeder et al., 2000; De la Llata et al., 2001; Mitchaothai et al., 2007).

The fatty acid levels in the LM are presented in Table 4. The fatty acid composition of muscle and fat tissues in the pig was known to be greatly modified by incorporating the appropriate oil source in feed, since the pig is a singlestomached animal and dietary fatty acids are absorbed intact in the small intestine and then incorporated into tissue lipids
(Wood et al., 1999). The myristic acid level and palmitoleic acid level were significantly higher $(\mathrm{p}<0.05$ for each) in the coconut oil group than in the other three groups. Also, the palmitic acid, one of SFA, was significantly higher $(\mathrm{p}<0.05)$ in the beef tallow and coconut oil groups compared with the olive oil group. Coconut oil diet suggested higher deposition of SFA, especially myristic acid, and lower deposition of UFA (both MUFA and PUFA). This result agrees with the findings of Jørgensen et al. (2000) in which a coconut oil diet highest SFA, especially 14:0 and 16:0, and lowest both MUFA and PUFA in pigs. The oleic acid level was significantly higher $(\mathrm{p}<0.05)$ in the olive oil group than in the beef tallow and soybean oil groups, but the oleic acid level in the coconut oil group was not significantly different from those in the beef tallow, soybean oil and olive oil groups. The linoleic acid and linolenic acid levels were significantly higher $(p<0.05)$ in the beef tallow and soybean oil groups than in the olive oil and coconut oil groups and also consistent with PUFA levels. Additionally, the stearic acid, gondoic acid, and arachidonic acid level in the LM were similar among all treatment groups. The increased linolenic acid content of pork from feeding provides the pork industry with an opportunity to provide

Table 4. The effect on dietary fat source on fatty acid of the LM in pigs ${ }^{1}$

\begin{tabular}{|c|c|c|c|c|c|}
\hline Items & Beef tallow & Coconut oil & Olive oil & Soybean oil & SE \\
\hline Myristic acid, C14:0 & $1.02^{\mathrm{b}}$ & $1.80^{\mathrm{a}}$ & $1.02^{\mathrm{b}}$ & $1.07^{\mathrm{b}}$ & 0.045 \\
\hline Palmitic acid, C16:0 & $22.18^{\mathrm{a}}$ & $22.40^{\mathrm{a}}$ & $21.11^{\mathrm{b}}$ & $21.54^{\mathrm{ab}}$ & 0.163 \\
\hline Palmitoleic acid, C16:1n7 & $2.47^{\mathrm{b}}$ & $3.12^{\mathrm{a}}$ & $2.52^{\mathrm{b}}$ & $2.20^{\mathrm{b}}$ & 0.072 \\
\hline Stearic acid, C18:0 & 12.30 & 11.81 & 11.29 & 12.02 & 0.173 \\
\hline Oleic acid, C18:1n9 & $29.95^{\mathrm{b}}$ & $32.47^{\mathrm{ab}}$ & $35.26^{\mathrm{a}}$ & $29.64^{\mathrm{b}}$ & 0.629 \\
\hline Linoleic acid, C18:2n6 & $25.69^{\mathrm{a}}$ & $22.54^{\mathrm{b}}$ & $22.76^{\mathrm{b}}$ & $27.67^{\mathrm{a}}$ & 0.410 \\
\hline Linolenic acid, C18:3n3 & $1.13^{\mathrm{a}}$ & $0.77^{\mathrm{b}}$ & $0.88^{\mathrm{b}}$ & $1.13^{\mathrm{a}}$ & 0.033 \\
\hline Gondoic acid, C20:1n9 & 0.49 & 0.57 & 0.62 & 0.45 & 0.029 \\
\hline Arachidonic acid, C20:4n6 & 4.80 & 4.53 & 4.54 & 4.27 & 0.256 \\
\hline SFA & $35.49^{\mathrm{ab}}$ & $36.00^{\mathrm{a}}$ & $33.42^{\mathrm{c}}$ & $34.63^{\mathrm{b}}$ & 0.192 \\
\hline UFA & $64.51^{\mathrm{bc}}$ & $64.00^{\mathrm{c}}$ & $66.58^{a}$ & $65.37^{\mathrm{b}}$ & 0.192 \\
\hline MUFA & $32.90^{\mathrm{b}}$ & $36.16^{\mathrm{ab}}$ & $38.40^{\mathrm{a}}$ & $32.29^{\mathrm{b}}$ & 0.686 \\
\hline PUFA & $31.62^{\mathrm{ab}}$ & $27.83^{b}$ & $28.19^{b}$ & $33.08^{\mathrm{a}}$ & 0.639 \\
\hline
\end{tabular}

\footnotetext{
${ }^{1}$ There were 18 pigs per diet group. The pooled SE from ANOVA is indicated.

${ }^{a, b}$ Means with different superscripts in the same row are different at $\mathrm{p}<0.05$.
} 
Table 5. Microarray analysis of gene expression relative to insulin signaling pathway in the LM in pigs ${ }^{1}$

\begin{tabular}{llll}
\hline Gene $^{2}$ & Symbol & Gene ID & p-value \\
\hline Phosphoinositide-3-kinase catalytic gamma polypeptide & PIK3CG & 396979 & 0.02400 \\
Protein kinase, cAMP-dependent, regulatory, type II & PRKAR2A & 397493 & 0.00374 \\
AMP-activated protein kinase alpha 2 & AMPKA2 & 397504 & 0.01671 \\
Peroxisome proliferator activated receptor,gamma,coactivator 1 & PPARGC1 & 397013 & 0.03581 \\
Protein phosphatase 1 catalytic subunit beta isoform & PPP1CB & 397378 & 0.02712 \\
\hline
\end{tabular}

${ }^{1}$ There were used for analyses 6pigs per diet groups.

${ }^{2}$ Gene expression was either increased or decreased by feeding fat type in growing-finishing pigs. GenPlex ${ }^{\mathrm{TM}} \mathrm{v} 2.4$ software was used for cluster analysis and mapping to relevant pathways based on information obtained from the Kyoto Encyclopedia of Genes and Genomes (KEGG) database. All genes listed exhibited at least a \pm 2 fold-change difference in expression (compared to fat type).

value-added by healthful meat products for human consumption (Sun et al., 2004). So, soybean oil was suggested a great alternative of beef tallow because linolenic acid was accumulated more than the olive oil and coconut oil groups in the LM.

Olive oil represented significantly the lowest SFA level and highest level of UFA among four oil group. The use of olive oil containing a high concentration of MUFA as a fat source is related to reduced rates for cardiovascular disease and breast cancer in humans (Kiritsakis, 1999). Diets rich in olive oil have been shown to produce reduced PUFA levels in red blood cell membranes (Seiquer et al., 1996) and decrease the prevalence of coronary heart disease in the Mediterranean region (Dougherty et al., 1987). Animal fat sources such as beef tallow have low apparent digestibility, which can be improved by mixing animal fat with various vegetable oils to increase the UFA and SFA ratio via increases in lipase activity (Powles et al., 1993; Powles et al., 1994; Mountzouris et al., 1999). This result indicates that LM content could be manipulated by dietary nutrients.

We measured and compared differential gene expression in the LM in three barrows for each dietary fat type. Microarray analysis classified according to the KEGG was shown significantly expressed genes in Table 5. It revealed significantly different expression levels at 6 genes relative to insulin signaling pathway $(\mathrm{p}<0.05)$.

The insulin signaling pathway in pigs involves a number of genes that control glucose storage and uptake, protein synthesis, and regulation of lipid synthesis. Insulin inhibits lipid metabolism by activating a cAMP-specific phosphodiesterase in adipocytes, thereby decreasing cellular cAMP concentrations (Kitamura et al., 1999). Because insulin signaling pathway was known that closely related to fat metabolism (Wong and Sul, 2010), the six genes were performed with RT-PCR confirming that the dietary fat source influenced the expression levels of these genes in pigs. The six genes were phosphoinositide-3-kinase, catalytic, gamma polypeptide (PIK3CG); protein kinase, cAMP-dependent, regulatory, type II, alpha (PRKAR2A); AMP-activated protein kinase alpha 2 (AMPKA2); peroxisome proliferator activated receptor, gamma, coactivator 1 (PPARGC1); protein phosphatase 1, catalytic subunit, beta isoform (PPP1CB); and hormone-sensitive lipase (HSL).

The expression levels of the six DEGs were estimated using the $\Delta \mathrm{Ct}$ method, and the results are shown in Table 7.

Table 6. List of DEGs for insulin signaling pathway and primers for RT-PCR

\begin{tabular}{|c|c|c|c|}
\hline Gene symbol & $\begin{array}{c}\text { Probe set ID } \\
\text { (Affymetrix chip) }\end{array}$ & $\begin{array}{l}\text { Primer sequences }\left(5^{\prime} \rightarrow 3^{\prime}\right) \\
\text { Forward/Reverse }\end{array}$ & $\begin{array}{l}\text { Product size } \\
\quad(\mathrm{bp})\end{array}$ \\
\hline PIK3CG & Ssc.11109.1.S1_at & $\begin{array}{l}\text { F:5'-TACGTCAGCAGGACAATCACCGAA-3' } \\
\text { R:5'-AACAGTCTCCAACATGACTGAGGG-3' }\end{array}$ & $199 \mathrm{bp}$ \\
\hline PRKAR2A & Ssc.16241.1.S1_at & $\begin{array}{l}\text { F:5'-CCAATTCCTAGCAGATTTGATCGGCG-3' } \\
\text { R:5'-GCATCGAGGACTTGAGAAAGTTGTTCC-3' }\end{array}$ & $197 \mathrm{bp}$ \\
\hline AMPKA2 & Ssc.16257.1.S1_at & $\begin{array}{l}\text { F:5'-AGGCGGTGTCTTTACTAGGTGAAC-3' } \\
\text { R:5'-TGGGCATAAACACAGCGTAAAGCC-3' }\end{array}$ & $203 \mathrm{bp}$ \\
\hline PPARGC1 & Ssc.16864.1.S1_at & $\begin{array}{l}\text { F:5'-GGGATGATGGAGACAGCTATGGTT-3' } \\
\text { R:5'-TGCTCTTGGTGGAAGCAGGATCAA-3' }\end{array}$ & $204 \mathrm{bp}$ \\
\hline PPP1CB & Ssc.5232.1.S1_a_at & $\begin{array}{l}\text { F:5'-GACACCCTTTATGATGTCACACCT-3' } \\
\text { R:5'-GATGTCTGTCCCTGTGAAGCATAC-3' }\end{array}$ & $197 \mathrm{bp}$ \\
\hline HSL & Ssc.6784.1.S1_at & $\begin{array}{l}\text { F:5'-CTTTGCGGGTATTCGGGAACA-3' } \\
\text { R:5'-ATGCTGCGGCGGTTGGA-3' }\end{array}$ & $192 \mathrm{bp}$ \\
\hline
\end{tabular}


Table 7. ANOVA table for each gene associated with feeding groups in barrows

\begin{tabular}{|c|c|c|c|c|c|c|}
\hline Gene & Source & df & Sum Sq & Mean Sq & $\mathrm{F}$ value & $\operatorname{Pr}(>\mathrm{F})$ \\
\hline \multirow[t]{2}{*}{ PIK3CG } & Feed & 3 & 0.022874 & 0.007625 & 1.6929 & 0.2668 \\
\hline & Residuals & 6 & 0.027023 & 0.004504 & & \\
\hline \multirow[t]{2}{*}{ PRKAR2A } & Feed & 3 & 0.025724 & 0.008575 & 8.1712 & $0.01535^{*}$ \\
\hline & Residuals & 6 & 0.006296 & 0.001049 & & \\
\hline \multirow[t]{2}{*}{ AMPKA2 } & Feed & 3 & 0.048914 & 0.016305 & 0.3786 & 0.7723 \\
\hline & Residuals & 6 & 0.258424 & 0.043071 & & \\
\hline \multirow[t]{2}{*}{ PPARGC1 } & Feed & 3 & 1.04196 & 0.34732 & 1.323 & 0.3514 \\
\hline & Residuals & 6 & 1.57515 & 0.26252 & & \\
\hline \multirow[t]{2}{*}{ PPP1CB } & Feed & 3 & 5.6216 & 1.8739 & 27.832 & $0.0006423 * * *$ \\
\hline & Residuals & 6 & 0.404 & 0.0673 & & \\
\hline \multirow[t]{2}{*}{ HSL } & Feed & 3 & 0.45812 & 0.15271 & 3.6696 & 0.08226 \\
\hline & Residuals & 6 & 0.24968 & 0.04161 & & \\
\hline
\end{tabular}

PIK3CG = Phosphoinositide-3-kinase, catalytic, gamma polypeptide; PRKAR2A = Protein kinase, cAMP-dependent, regulatory, type II; AMPKA2 = AMP-activated protein kinase alpha 2; PPARGC1 = Peroxisome proliferator activated receptor, gamma, coactivator 1; PPP1CB = Protein phosphatase 1, catalytic subunit, beta isoform; HSL $=$ Hormone-sensitive lipase.

**** Significant differences ( $\mathrm{p}<0.05$ and 0.001 ) among the feeding groups determined using the mixed ANOVA module.

In particular, the PRKAR2A and PPP1CB genes showed marked differential expression according to dietary oil composition. It showed significant differences in expression among the four dietary oil groups, with the highest expression level in the olive oil group (Figure 1). PRKAR2A is an important signaling molecule in the regulation of metabolism and growth of mammalian cells (Hemmings et al., 1986). PPP1CB is one of the three catalytic subunits of protein phosphatase 1 (PP1), which is involved in the regulation of a variety of cellular processes such as cell division, glycogen metabolism, muscle contractility, and protein synthesis (Cohen, 1997). Especially, the PPP1CB gene is known to be related to glycogenesis, which is activated by insulin in response to high glucose levels.

As the PUFA (linoleic and $\alpha$-linolenic acid) cannot be synthesized in situ, the tissue concentrations respond rapidly to dietary changes. However, SFA and MUFA are synthesized de novo, and therefore their concentrations are less readily influenced by diet (Wood, 1984).

The PRKAR2A and PPP1CB genes showed the highest level of expression in the olive oil group with the highest levels of MUFA and the lowest level of expression in the coconut oil group with the lowest levels of MUFA. The expression of PRKAR2A and PPP1CB genes in Figure 1 is highly matched with ratio of the amount of MUFA at the oils of four types (Beef tallow $44 \mathrm{~g} / 100 \mathrm{~g}$, Coconut 6.6 g/100 g, Olive 69.7 g/100 g, Soybean 23.2 g/100 g) (Food Standards Agency, 1991). The oils were shown a large difference in the amount of MUFA, but the ratio of the MUFA content in LM did not shown a large difference each other in dietary group. So, these results were shown that

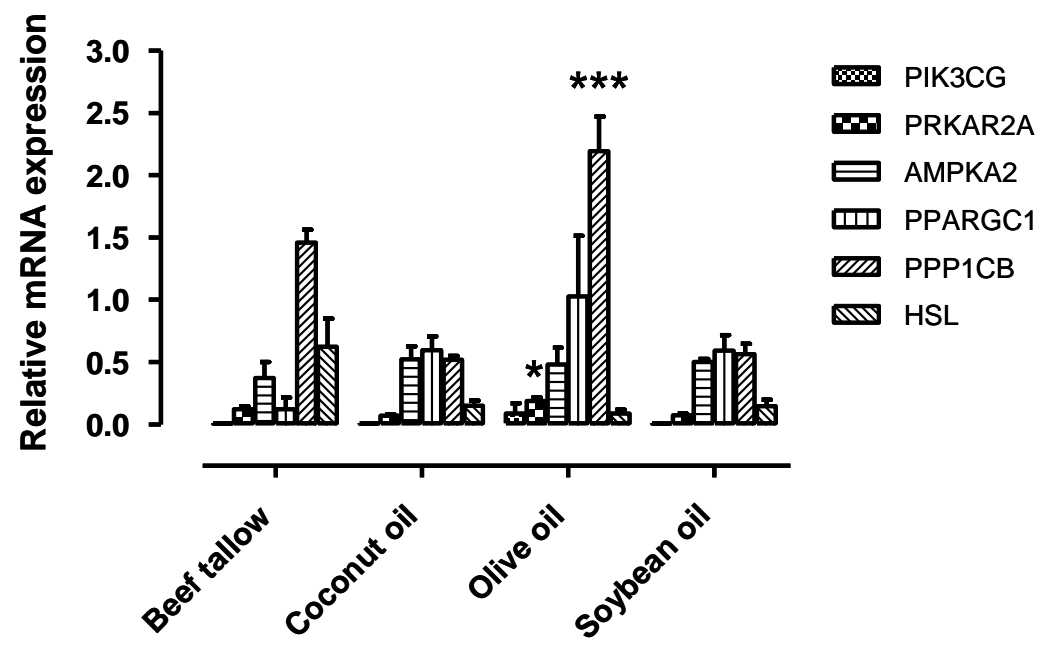

Figure 1. Expression patterns of differentially expressed genes with qRT-PCR at the 4 dietary oil groups. Fat sources were beef tallow, coconut oil, olive oil, and soybean oil, which were added to a concentration of $3.0 \%$ in feed. The experiments were performed using the LM 3 barrows, and data are expressed as mean \pm SE. The asterisks show statistically significant values $(* \mathrm{p}<0.05, * * \mathrm{p}<0.01)$. 
expression of PRKAR2A and PPP1CB genes inversely matched with accumulation of MUFA in LM. Gene expression increased by absorbed a lot of MUFA, and it was suggested that the accumulation of MUFA in LM relatively declined by increased genes.

Dietary factors and related metabolic interactions have direct and indirect nutrient influences on the regulation and expression of specific genes. It has been suggested that significant regulation occurs at the level of transcription, with controlled modulation of mRNA levels. It indicates that nutritional factors can also regulate gene expression by interacting with other regulatory networks depending on dietary fat. Other studies have demonstrated the regulation of apoprotein gene expression by a sucrose-rich diet, the nutritional regulation of gene expression in lipogenesis, and the suppression of fatty acid synthase transcription by PUFAs (Walker and Blackburn, 2004). PUFAs and hormones (leptin, adiponectin) that activate AMP-activated protein kinase have been reported to improve insulin sensitivity in rats (Suchankova et al., 2005).

As the result, it has been speculated these genes play an important role in the control of MUFA. Therefore, these results suggest that both genetic and nutritional factors should be considered for fatty acid composition in the LM. These results are due to the different expression of genes involved in insulin signaling pathway, but that will need to be confirmed by enzyme activity and protein function studies.

\section{CONCLUSION}

This study indicates that fat type had no significant effect on chemical composition and on meat quality as well as on growth performance in growing-finishing pigs. However, it could be manipulated by dietary nutrients because dietary fat type affected fatty acid composition in the LM contents. Especially, soybean and olive oil could be a substitute for beef tallow as commonly used fat additives. The six genes associated with insulin signaling pathway identified difference of the expression by microarray analysis. In particular, PRKAR2A and PPP1CB at the LM showed the highest expression level in the olive oil group. Expression of PRKAR2A and PPP1CB genes inversely matched with accumulation of MUFA in LM. Gene expression increased by absorbed a lot of MUFA, and it was suggested that the accumulation of MUFA in LM relatively declined by increased genes. The results of this study indicate that the type of dietary fat affects fatty acid composition and insulin signaling-related gene expression in the LM of pigs.

\section{ACKNOWLEDGEMENTS}

This study was supported by Agenda (200901OFT
072148173) of National Institute of Animal Science, Rural Development Administration, Republic of Korea.

\section{REFERENCES}

Andersen, H. J., N. Oksbjerg, J. F. Young and M. Therkildsen. 2005. Feeding and meat quality - a future approach. Meat Sci. 70:543-554.

AOAC, 1990. Official methods of analysis, 15th ed. Assoc. Off. Anal. Chem., Washington, DC, USA.

Cera, K. R., D. C. Mahan and G. A. Reinhart. 1988. Effects of dietary dried whey and corn oil on weanling pig performance, fat digestibility and nitrogen utilization. J. Anim. Sci. 66: 1438-1445.

Cera, K. R., D. C. Mahan and G. A. Reinhart. 1989. Apparent fat digestibilities and performance responses of postweaning swine fed diets supplemented with coconut oil, corn oil or tallow. J. Anim. Sci. 67:2040-2047.

Cera, K. R., D. C. Mahan and G. A. Reinhart. 1990. Evaluation of various extracted vegetable oils, roasted soybeans, mediumchain triglyceride and an animal-vegetable fat blend for postweaning swine. J. Anim. Sci. 68:2756-2765.

Cohen, P. T. W. 1997. Novel protein serine/threonine phosphatases: Variety is the spice of life. Trends Biochem. Sci. 22:245-251.

Corino, C., S. Magni, E. Pagliarini, R. Rossi, G. Pastorelli and L. M. Chiesa. 2002. Effects of dietary fats on meat quality and sensory characteristics of heavy pig loins. Meat Sci. 60:1-8.

De la Llata, M., S. S. Dritz, M. D. Tokach, R. D. Goodband, J. L. Nelssen and T. M. Loughin. 2001. Effects of dietary fat on growth performance and carcass characteristics of growingfinishing pigs reared in a commercial environment. J. Anim. Sci. 79:2643-2650.

Dougherty, R., C. Galli, A. Ferro-Luzzi and J. Iacono. 1987. Lipid and phospholipid fatty acid composition of plasma, red blood cells, and platelets and how they are affected by dietary lipids: a study of normal subjects from Italy, Finland, and the USA. Am. J. Clin. Nutr. 45:443-455.

Eder, K., G. Müller, H. Kluge, F. Hirche and C. Brandsch. 2005. Concentrations of oxysterols in meat and meat products from pigs fed diets differing in the type of fat (palm oil or soybean oil) and vitamin E concentrations. Meat Sci. 70:15-23.

Ewan, R. C. 1970. Effect of protein quality on fat utilization by baby pigs. J. Anim. Sci. 31:1020. (Abstr).

Folch, J., M. Lees and G. H. Sloane-Stanley. 1957. A simple method for the isolation and purification of total lipides from animal tissues. J. Biol. Chem. 226:497-509.

Food Standards Agency. 1991. Fats and oils. McCance \& Widdowson's the Composition of Foods. Royal Society of Chemistry.

Hemmings, B. A., M. Schwarz, S. Rao Adavani and D. A. Jans. 1986. Expression cloning of a cDNA encoding the type II regulatory subunit of the cAMP-dependent protein kinase. FEBS Lett. 209:219-222.

Honikel, K. O. 1998. Reference methods for the assessment of physical characteristics of meat. Meat Sci. 49:447-457.

Howard, K. A., D. M. Forsyth and T. R. Cline. 1990. The effect of an adaptation period to soybean oil additions in the diets of young pigs. J. Anim. Sci. 68:678-683. 
Jørgensen, H., V. M. Gabert, M. S. Hedemann and S. K. Jensen. 2000. Digestion of fat does not differ in growing pigs fed Diets containing fish oil, rapeseed oil or coconut oil. J. Nutr. 130: 852-857.

Jauregui, H., N. Hayner, J. Driscoll, R. Williams-Holland, M. Lipsky and P. Galletti. 1981. Trypan blue dye uptake and lactate dehydrogenase in adult rat hepatocytes-Freshly isolated cells, cell suspensions, and primary monolayer cultures. In Vitro Cellular \& Developmental Biology - Plant 17:1100-1110.

Kiritsakis, A. 1999. Composition of olive oil and its nutritional and health effect. In: Proceeding of the 10th International Rapeseed Congress, Canberra, Australia, 205-209.

Kitamura, T., Y. Kitamura, S. Kuroda, Y. Hino, M. Ando, K. Kotani, H. Konishi, H. Matsuzaki, U. Kikkawa, W. Ogawa and M. Kasuga. 1999. Insulin-induced phosphorylation and activation of cyclic nucleotide phosphodiesterase $3 \mathrm{~B}$ by the serine-threonine kinase Akt. Mol. Cell. Biol. 19:6286-6296.

Li, D. F., R. C. Thaler, J. L. Nelssen, D. L. Harmon, G. L. Allee and T. L. Weeden. 1990. Effect of fat sources and combinations on starter pig performance, nutrient digestibility and intestinal morphology. J. Anim. Sci. 68:3694-3704.

McDonald, B. E. and R. M. G. Hamilton. 1976. Growth and carcass composition of pigs fed diets that contained rapeseed oil, soybean oil or tallow during the growing period. Can. J. Anim. Sci. 56:671-680.

Mitchaothai, J., C. Yuangklang, S. Wittayakun, K. Vasupen, S. Wongsutthavas, P. Srenanul, R. Hovenier, H. Everts and A. C. Beynen. 2007. Effect of dietary fat type on meat quality and fatty acid composition of various tissues in growing-finishing swine. Meat Sci. 76:95-101.

Mountzouris, K. C., K. Fegeros and G. Papadopoulos. 1999. Utilization of fats based on the composition of sow milk fat in the diet of weanling pigs. Anim. Feed Sci. Technol. 77:115-124.

Noblet, J., H. Fortune, X. S. Shi and S. Dubois. 1994. Prediction of net energy value of feeds for growing pigs. J. Anim. Sci. 72: 344-354.

NRC. 1998. Nutrient requirements of swine. 10th ed. National Academy Press, Washington, DC, USA.

Overland, M., M. D. Tokach, S. G. Cornelius, J. E. Pettigrew and J. W. Rust. 1993. Lecithin in swine diets: I. Weanling pigs. J. Anim. Sci. 71:1187-1193.

Powles, J., J. Wiseman, D. J. A. Cole and B. Hardy. 1993. Effect of chemical structure of fats upon their apparent digestible energy value when given to growing/finishing pigs. Anim. Sci. 57:137-146.

Powles, J., J. Wiseman, D. J. A. Cole and B. Hardy. 1994. Effect of chemical structure of fats upon their apparent digestible energy value when given to young pigs. Anim. Sci. 58:411-417.

Scheeder, M. R. L., K. R. Gläser, B. Eichenberger and C. Wenk. 2000. Influence of different fats in pig feed on fatty acid composition of phospholipids and physical meat quality characteristics. Eur. J. Lipid Sci. Technol. 102:391-401.
Seerley, R. W., J. P. Briscoe and H. C. McCampbell. 1978. A comparison of poultry and animal fat on performance, body composition and tissue lipids of swine. J. Anim. Sci. 46:10181023.

Seiquer, I., E. Martinez-Victoria, M. Mañas, J. R. Huertas, M. C. Ballesta and F. J. Mataix. 1996. Long term effects on lipid metabolism in miniature swine (Sus scrofa) of diets enriched in saturated, monounsaturated and polyunsaturated (n-6 and n3) fatty acids. Arch. Physiol. Biochem. 104:20-29.

Spencer, J. D., A. M. Gaines, E. P. Berg and G. L. Allee. 2005. Diet modifications to improve finishing pig growth performance and pork quality attributes during periods of heat stress. J. Anim. Sci. 83:243-254.

Suchankova, G., M. Tekle, A. K. Saha, N. B. Ruderman, S. D. Clarke and T. W. Gettys. 2005. Dietary polyunsaturated fatty acids enhance hepatic AMP-activated protein kinase activity in rats. Biochem. Biophys. Res. Commun. 326:851-858.

Sun, D., X. Zhu, S. Qiao, S. Fan and D. Li. 2004. Effects of conjugated linoleic acid levels and feeding intervals on performance, carcass traits and fatty acid composition of finishing barrows. Arch. Anim. Nutr. 58:277-286.

Teye, G. A., P. R. Sheard, F. M. Whittington, G. R. Nute, A. Stewart and J. D. Wood. 2006. Influence of dietary oils and protein level on pork quality. 1. Effects on muscle fatty acid composition, carcass, meat and eating quality. Meat Sci. 73: $157-165$

Tokach, M. D., J. E. Pettigrew, L. J. Johnston, M. Overland, J. W. Rust and S. G. Cornelius. 1995. Effect of adding fat and(or) milk products to the weanling pig diet on performance in the nursery and subsequent grow-finish stages. J. Anim. Sci. 73: 3358-3368.

Van Deckel, M. J., M. Casteels, N. Warnants, L. Van Damme and C. V. Boucqué. 1996. Omega-3 fatty acids in pig nutrition: Implications for the intrinsic and sensory quality of the meat. Meat Sci. 44:55-63.

Walker, W. A. and G. Blackburn. 2004. Symposium introduction: Nutrition and gene regulation. J. Nutr. 134:2434S-2436S.

Ways, P. and D. J. Hanahan. 1964. Characterization and quantification of red cell lipids in normal man. J. Lipid Res. 5: 318-328.

Wong, R. H. F. and H. S. Sul. 2010. Insulin signaling in fatty acid and fat synthesis: a transcriptional perspective. Curr Opin Pharmacol. 10:684-691.

Wood, J. D. 1984. Fat deposition and the quality of fat tissue in meat animals. Fats in Animal Nutrition, 407-435 (Ed. J. Wiseman). London: Butterworths.

Wood, J. D., M. Enser, A. V. Fisher, G. R. Nute, R. I. Richardson and P. R. Sheard. 1999. Manipulating meat quality and composition. Proc. Nutr. Soc. 58:363-370.

Yin, J. and D. Li. 2009. Nutrigenomics Approach - A strategy for identification of nutrition responsive genes influencing meat edible quality traits in swine. Asian-Aust. J. Anim. Sci. 22: 605-610 